UDC [94:328.1](477.8)«1944/1951»

DOI: $10.24919 / 2519-058 x .7 .132752$

Olexandra STASIUK,

orcid.org/0000-0002-2957-0432

Ph D hab. (History), Senior Researcher of Department of Modern History,

I. Krypiakevych Institute of Ukrainian Studies of the NAS of Ukraine

(Ukraine,Lviv)ol_stasuk@ukr.net

\title{
THE PECULIARITIES OF FORMATION OF THE REPRESENTATIVE \\ BRANCH OF POWER IN THE WEST UKRAINIAN REGIONS OF THE UKRAINIAN SOVIET SOCIALIST REPUBLIC IN THE POST-WAR PERIOD
}

The articletreats of the features of formation of the representative branch of power in the West Ukrainian regions (oblasts) of the post-war period in relation to other regions of the Ukrainian Soviet Socialist Republic. The losses of the deputy corps of the Ukr. SSR of the first convocation during the war and their causes are disclosed, the statistical data is cited. The intrusion of the regime into the process of restoration of local Soviets (soviets, radas) in 1944-1945 is shown. The accent is made on a full submission of the process to the control of the party authorities. The qualitative structures of deputy representatives of different levels of the second and third convocations from the West Ukrainian regions in the Supreme Soviets of the USSR and Ukr. SSR, as well as the local soviets, are characterised. The political, social, national, and gender differences of the deputy representatives of the West Ukrainian oblasts in relations to the diplomatic corps of the Ukr. SSR and the structure of the "people's» electees of the East Ukrainian regions are specified. The conclusion is made about the artificial nature of the process of formation of the deputy corps in the Ukrainian Soviet Socialist Republic with the aim to demonstrate the participation of all social classes in the state government and to prove the democratic character of the regime.

Key words: West Ukrainian regions of the USSR, post-war period, representative branch of power, deputy corps.

Олександра СТАСЮК, кандидат історичних наук, старший науковий співробітник відділу новітньої історї Інституту украӥнознавства ім. I. Крип'якевича НАН Украӥни

(Україна, Львів) ol_stasuk@ukr.net

\section{ОСОБЛИВОСТІ ФОРМУВАННЯ ПРЕДСТАВНИЦЬКОЇ ГІЛКИ ВЛАДИ У ЗАХІДНОУКРАЇНСЫКИХ ОБЛАСТЯХ УКРАЇНСЬКОЇ РСР ПОВОСННОГО ПЕРІОДУ}

У статті висвітлено особливості формування представницької гілки влади в західноукраӥнських областях повоєнного періоду у стосунку до інших регіонів Української РСР. Виявлено втрати депутатського корпусу УРСР першого скликання за час війни та їх причини, наведено статистичні дані. Показано втручання режиму у прочес відновлення місиевих рад у 1944 - 1945 роках. Наголошено на повній підконтрольності прочесу партійним органам влади. Охарактеризовано якісний склад депутатського представниитва різних рівнів другого та третього скликань від західноукраӥнського регіону у ВР СРСР та УРСР, а також місцевих рад. Вказано на політичні, сочіальні, національні, та гендерні відмінності депутатського представництва від західноукраӥнських областей у стосунку до дипкорпусу УРСР та складу «народних обранців» східноукраӥнського регіону. Зроблено висновок про штучність процесу формування депутатського корпусу в Украӥнській РСР з метою продемонструвати участь всіх верств суспільства в управлінні держсавою та довести демократичність режиму.

Ключові слова: західноукраїнські області УРСР, повоєнний період, представницька гілка влади, депутатський корпус. 
Problem statement. The formation and development of democratic institutions of the independent Ukraine are in the centre of attention of domestic and foreign scholars. The study of these problems, in particular, from the point of view of a historical retrospective, is important for the search of of optimum ways of reforms and timely reaction to political crises and present day challenges. In view of that, the West Ukrainian regions are most attractive to scholars and have a powerful potential for the solution of many national and state-buolding problems.

The analysis of researches. In the historiography the chances in cadres in the West Ukrainian regions after their joining to the Ukr. SSR many works are dedicated. This problem many the Soviet scholars usually treated with a marked underlining of the progressive role of the party cadres and experts in different areas from the East Ukrainian regions in the Sovietization of Western Ukraine (Vlaskin, 1966), (Trofymiak, 1970), (Kirsanova, 1981). However, they ignored negative sides of the process. The works of modern domestic scholars are marked with new approaches to studying of the specified problem which are based on conceptual statements about a violent character of the change of political elite of the West Ukrainian regions, the regime's mistrust in the local intelligentsia, a low educational level of the part-Soviet activists sent by the Central Committee (CC) for the Sovietization of the regions, an aggravation on this basis of social and national contradictions, etc. (Voslenskyi, 1991), (Kondratiyk, Leskiv, 2005), (Dokash, 2013). However, the specified researches mainly concern the personnel structure of party and executive structures, heads of leading establishments and enterprises, but, at the same time, the quantitative and qualitative structure of the representative branch of power of different levels is not sufficiently analysed. In addition, the researchers do not single out the West Ukrainian representatives from the total number of deputies of the Ukrainian Soviet Socialist Republic, and, accordingly, do not pay attention to the regional characteristics of the diplomatic corps.

The purpose of the article is to elucidate the features of formation of the representative branch of the bodies of power of different levels in the West Ukrainian regions in the postwar period in their relation to the other regions of Ukr. SSR on the basis of archival sources. Besides, the purpose of this article includes finding out regional features of quantitative and qualitative structure of the deputy representation in the Supreme Sovietss (SS) of the USSR, Ukr. SSR, and local authorities.

The statement of the basic material. Despite the fact, that the term of functioning of the Supreme Soviets of the USSR, its republics and local authorities of the first cadence had expired yet in 1941-1942, the representatives of the regime during the post-war period did not hasten to restore the representative institutions, primerily adjusting the work of the executive branch of power, party and power structures. For that there were several reasons. First, the work of the representative branch of power in the Soviet Union was of secondary value in the control system of the state and. also, was ineffective. Actually, Sovietsbut duplicated the party's power's vertical, creating a visibility of democracy. Secondly, the war and connected with it material and human losses led to an excessive radicalization of public mood, so that Moscow was afraid that the system of operated democracy could get out of the party control. Many additional problems were connected with the financial difficulties, shortage of the human resource, insufficient probation of the new elective legislation, and so on. After all, the basic reason for postponing the election campaign was the necessity to oppose the national-liberation movements in the occupied after the Second World War regions (the Baltic republics, Western Ukraine, Western Belorussia, Bukovyna, and Transcarpathia). 
The movement of the Ukrainian nationalists under the leadership of OUN and UPA in West Ukrainian regions was particularly dangerous for the power, as it actively counteracted the establishment of the Soviet regime and threatened to extend the activity to the whole republic's territory. Underestimating the strength of the Ukrainian insurgents, the representatives of the regime expected to cope with them during crossing of the fronts, but, nevertheless, the struggle went on for years, so in the West Ukrainian regions the power was compelled to conduct the first elections of the representative branch of power at the background of a sharp military-political conflict which at the break of 1945-1946 reached its peak of development. It created definitehardships for the power in the course of preparation and organization of the elections, but did not influence in any way the formation of structure of the deputy corps which was defined in the party offices long before the voting process.

During the war the numerical structure of the deputy corps of the USSR and Ukr. SSR were sharply reduced. From the total of deputies who balloted from the Ukrainian Soviet Socialist Republic to the Supreme Soviet of the USSR of the first convocation, 28 were subjected to repression and 22 perished (the List of deputies of the SS of the USSR of the first convocation). 22 persons from among the deputies of the SS of the Ukr. SSR left the structure of the deputy corps for various reason (were killed at the front, subjected to repression, shot by the Germans, liquidated by the Banderites, sent to Germany, taken prisoner, etc.). By the beginning of 1946 the representatives of the power had no uniform information about 13 people's electees of the SS of the Ukr. SSR of the first convocation (CSAHAB of Ukraine. Fund 1. Description 31. Case 2. Pages 1-82). As a result at the sixth session of SS of the Ukr. SSR in March, 1944, which considered problems of post-war restoration of the country, only 2/3 deputieswere present. By May 1st, 1945289 persons or $72 \%$ out of 400 deputies of the Supreme Soviet of the Ukr.SSR of the first convocation were within the republic. By the beginning of 1946 it became possible to restore over $80 \%$ of the pre-war deputy structure of the SS of the Ukr. SSR, but almost $20 \%$ were lost for ever (The history of the state service in Ukraine: $342-345$ ).

In particular,large losses were observed at the local level. For example, of the corresponding quantity of deputies of country Soviets of the Ukr. SSR of the first convocation by the beginning of 1945 only $50 \%$ remained, of city Soviets' deputies only $33 \%$ remained, of regional Soviets' deputiesonly $29 \%$ remained, and of rural ony $40 \%$ remained (Dokash: 11-16). In the West Ukrainian regions those losses were still larger: of 76 deputies of Lviv region Soviet, elected in 1940, by January 1st, 1945 only 32 men (42\%), of 73 deputies of Drohobych region Soviet only 23 persons (31\%), and of 29 deputies of Rivneregion only 13 persons (44\%) were documentally fixed (The quantitative and qualitative structure of deputies of regional Soviets of deputies of workers). That is, on average, the regional Soviet of the West Ukrainian regions by the beginning of 1945 was filled only for 35-40 \%. The district Soviets here were presented only by a few electees, and in many village Soviets remained no electees at all. In particular, in Lviv region in Peremyshliany district Soviet of 51 deputies, elected in 1940, only 3 remained, in Bibrka district Soviet of 40 deputies 8 remained. (SALR. Fund 221. Description 2. Case 1766. Pages 61, 65.).

In their response to the inquiry of the Presidium of the Supreme Soviet of the Ukr.SSR which demanded in February, 1945 to be informed on the available structure of deputies of the first convocation, the local power bodies complained that to find the whereabouts of the majority of the former deputies was impossible through the loss of that time records and fluidity of the population. Moreover, Mr Dmytrysh, the secretary of Rivne region Soviet's 
executive committee, on April, 10th, 1945 informed that in 6 districts of the region it was impossible to establish the exact data about the structure of their Soviets as the archives did not keep out and there remained no people who could give the information (CSAHAB of Ukraine.Fund 1. Description 20. Case 4. Page 112).

The reduction of the number of deputies in the West Ukrainian regions, except all-Union factors, had a number of additional circumstances. E. g., many of "people's electees" of the village and district Soviets perished from the hands of the Banderites, many other emigrated to the West or- for various reason were -hid from the Soviet power, livingin illegal position. The flow of deputies also took place because of specification of the western border after the end of the Second World War. D. Roman, the secretary of Drohobych regional Soviet of deputies of workers' Executive committee, informed the Presidium of the SS of the Ukrainian Soviet Socialist Republic in his reference of February 9, 1945 that the reduction of the quantity of deputies was connected with the withdrawal of a part of Drohobych region's territory to Poland (CSAHAB of Ukraine.Fund 1. Description 20. Case 4. Page 52). And in Sokal land, which was attached to the Ukr. SSR during the post-war period (in exchange for oil deposits in Dobromyl territory), the deputies to the Soviet representative bodies of power were not electedat all.

Proceeding from it, the Central Committee (CC) in its act of April 1st, 1944 "On administrative bodies of the local Soviets of workers' deputief" decided to restore the Soviets and their executive committees at the expense of the local party and Soviet's activists. That is, the structure of local Soviets began to be filled «manually» with the necessary people, and with neglect of democracy principles. In view of this, byJanuary, 1st, 1947 throughout the Ukrainian Soviet Socialist Republic in regional Soviets 37,7 \% of the persons had no deputy mandates. In district Soviets this figure was $23,8 \%$, and in village Sovietsit was $32,3 \%$ ) (CSAHAB of Ukraine.Fund1 were deputies only. Description 30. Case 589. Page 7).

The election campaigns carried out in 1946-1947 brought about the next structure of deputy corps of the SS of theUSSR, and republics and local Soviets, which was renewed almost in $80 \%$. Nut even the cardinal renewak of the structure of the representative branch of power did not make its activity more efficient and did not reduce their dependence on the party structures. Supervising the elections at each stage, the representatives of the regime took care, that exclusively loyal to the power citizens got into the representative bodies. In particular,all care was taken in order no persons who co-operated with the Nazis or participants of the national-liberation movement, or were in a captivity were elected there. That is, Stalin and his supporters once again generated pocket representations with a very extremely limited right of voteat different levels of the Soviet branch of power.

The qualitative structure of deputy corps of the Ukr. SR of the second convocation in the core kept the tendencies planned during 1938-1941 election campaigns, although separate indicators showed variability. E. g., joining of the West Ukrainian territories to the Ukr. SSR made deputy structure of the SS of the Ukr. SSR more Ukrainian. If in the SS of the Ukr. SSR of the first convocation elected in 1938 the Ukrainians made up 45- $50 \%$ on average, the deputy corps of the second convocation had already 296 Ukrainians (71\%), and the third had 309 (73\%). As a part of the representation to SS of the Ukr. SSR from the West Ukrainian regions of the second convocation there were still more Ukrainians, namely, 83 representatives $(86 \%)$, and of the third they were $86(90 \%)$. The quantity increase of the representatives of the Ukrainian nationality in the diplomatic corps was linked with the party instructions to more acticely promote the representatives of the local populationin the West 
Ukrainian regions on to administrative posts, and a relative liberalisation of the national policy of the regime during the post-war period in general. However, in 1960s - 1980s the quantity of Ukrainians among deputies constantly decreased, and. at the same time, the quantity of Russians and representatives of other nationalities increased. In addition, a considerable part of deputies-Ukrainians belonged to the Russified persons who did not know the Ukrainian language and culture, and who imagined themselves inferior elements.

To the second - by the quantity -national group in the SS of the Ukr. SSR the Russians belonged, whoin the parliament of the second convocation made up 110 members. $(27 \%)$, and in that of the third convocation they were $102(24 \%)$. Taking into consideration, that the number of Russians in the population of the Ukrainian Soviet Socialist Republic in 1930s 1940s was approximately $10 \%$, their representation in the SS of the Ukr. SSR was evidently overestimated. Especially, it was inconsistently large among the deputies from the West Ukrainian regions where Russians as a national minority made up no more than 2 percent of the local population. So, to the SS of the Ukr. SSR of the second and of the third convocations from the West Ukrainian regions $13(14 \%)$ and 10 (10 \%) Russions respectively were elected. To the representative branch of power of the Ukrainian Soviet Socialist Republic, besidesthe Ukrainians and Russians, persons of other nationalities (Georgians, Jews, Armenians, Byelorussians, and others) were elected, whose quantity, however, did not exceed 1,5\% (CSAHAB of Ukraine traditionally got. Fund 1. Description 20. Case 119. Page 3).

In particular, the national palette of local Soviets was motley. E. g., on December 21, 1947 to the local Soviets in Ukr. SSR the following members were elected: Jews -3.748 $(1,22 \%)$, Poles $-1.817(0,6 \%)$, Bulgarians $-1.367(0,4 \%)$, Byelorussians - $1.154(0,38 \%)$, Greeks - $684(0,22 \%)$, Romanians- $604(0,2 \%)$, Czechs - $90(0,03 \%)$, Tatars- $92(0,03 \%)$, Latvians - $37(0,01 \%)$, Mordvinians - 39, Georgian - 33, Albanians - 30, Chuvashs - 27, Lithuanians-23, Ossetins - 21, Uzbeks - 11 (CSAHAB of Ukraine.Fund1. Description 18. Case 50. Page 13). However, in the West Ukrainian regions to local Soviets mainly Ukrainians, Russians, Poles, and Jews were elected. For example, to Lviv regional Soviet of the second convocation in December 194770 Ukrainians and only 10 Russians were elected (State Archive of Lviv Oblast. Fund 231. Description 2. Case 244. Page 1).

The characteristics of deputy structure by political signs, certainly, were not marked by a great variety. There were regional and village Soviets in which structure there were only Ukrainians. Among deputies, the members and candidates in members of the All-Union Communist party (of the Bolsheviks) and the Communist party (of the Bolsheviks) of Ukraine, as also Komsomol members prevailed. The rest were such who did not belong to the partyy, privately depended on the party colleagues, and had no possibility to represent separate thoughts. The quantity of the party members constantly increased. Thus, to the Ukr. SSR's regional Soviets in December, 194717.048 or $62 \%$ of the general structure of deputies of regional Soviets elected were party members, and during a similar elections of 1950 their quantity already made up 17.963 (64,8\%).

Comparatively less persons with party membership cards were in the representative branch of power of different levels in the West Ukrainian regions.Thus, in the SS of the Ukr. SSR of the second convocation there were $79,76 \%$ of members and candidates for membership, whereas their representation in the West Ukrainian regions was $73,96 \%$. In particular low quantity of party members was observable in the environment of delegations of local Soviets of the West Ukrainian regions, becausethe promoted workers from among the locals mainly were not party members. For an example: on December 21, 194719 party members 
were elected to Vinnytsia regional Soviet, 23 were elected to Stalin regional Soviet, 18 were elected to Poltavaregional Soviet, 22 were elected to Kharkiv regional Soviet, 9 were elected to Volhynian regional Soviet, 7 were elected to Drohobych regional Soviet, 10 were elected to Lvivregional Soviet, 8 were elected to Rivne regional Soviet, and 6 were elected to Stanislaviv regional Soviet (CSAHAB of Ukraine. Fund R-1. Description 18. Case 44. Page 43). 140 party members were elected to district Soviets in Voroshylovohrad region, 199 were elected to those in Zhytomyr region, 159 were elected to those in Poltava region, 62 were elected to those in Volhynian region, 51 were elected to those in Drohobych region, 58 were elected in Lviv region, 39 were elected in Stanislaviv region, and 26 were elected to those in Ternopil 'region (CSAHAB of Ukraine.Fund R-1. Description 18. Case 44. Page 109).

The proportion of deputies who balloted from the West Ukrainian regions, the number of the natives of other regions of the Ukrainian Soviet Socialist Republic and even of the Russian Soviet Socialist Republic was ever high. Those were the proteges of the party sent to Western Ukraine to make the Soviet transformations. As a rule, they were the first to get to the structure of representative delegations, acquiring the right to represent the thought of the region's population in the SS of the USSR and Ukr. SSR. Whereas the inhabitants of the East Ukrainian regions elected the representatives mainly from the local cadres. Thus, of 15 candidates in the deputies to the SS of the Ukr. SSR of the second convocation in Ternopil region there were only 5 locals (BSA of the SSU.Fund13.Case376. Vol. 38. P. 85), while in Voroshylovohrad region this ratio was 18 and 13 (BSA of the SSU.Fund13.Case376. V. 38. Page 70).

The administrative and professional posts of candidates in deputies were not marked by a freart variety. The state and party figures of republican, regional and regional levels, leaders of the NKVS (Ministry of Internal Affairs) and NKDB (MGB, Ministry of State Security), heads of large enterprises, high military ranks, chairmen of the village Soviets and collective farms, and the like superiors became promoters of the case of workers and peasants. This all-union practice without changes was applied in the western regions. Particularly, among candidates in the deputies to the SS of the Ukr. SSR from the West Ukrainian regions of the second convocation were such: the well-known Soviet and party figure D.Z. Manuiilskyi, the Heroes of the Soviet Union K.M. Halytskyi and M.I. Naumov, major-general O.V. Chapayev,the son of the known guerrilla leader Vasily Chapayev, one of leading figures of the Ministry of Internal Affairs and the KGB of the RSFR A.O. Nikiforov, and others. At the same time, from among the local population they elected mainly the members of the CPWU and physical laborer (successive collective farmers and workers), who for the lack of education often could not carry out not only legislative, but also representative functions. The power had it that the well checked up people and those devoted to the party should be dominant in the higher echelons of power, therefore, the aforementioned tendency remained for long time. In particular, to the Council of Nationalities of the SS of the USSR on March, 12, 1950 from the West Ukrainian regions 6 representatives were elected, of them 2 secretaries of regional party organizations, 3 chairmen of executive committee, and one chairman of a collective farm, all members and candidates in members of CP of Ukraine. (CSAHAB. Fund 1. Description 20. Case 233. Page 1). In the rest regions of the Ukr. SSR which population already had well acquired the rules of the Soviet electoral games, the power could operate in a more more democratic manner. Here they proposed much more workers and peasants to be electees. So, from the Dnipropetrovsk and Zaporizhiaregions to the Council of Nationalities of the SS of the USSR in 1950 from among the nomenclature workers only two secretaries of executive 
committees of regional Soviets were elected, of Voroshylovohrad region just one secretary of the city CP organization was elected, of Kiev region alsp one minister was elected, and in the rest were regions workers and employees, including poets Rylskyi and Tychyna (CSAHAB of Ukraine.Fund1. Description 20. Case 233. Pages 6-8).

In general, the percentage of workers and peasants as deputies of SS of the USSR and Ukr. SSR in the studied period was insignificant and constantly decreasing. Wishin to prove that the SS of the Ukr. SSR really has national representation, at conclusion of statistical data chairmen of collective farms, heads of MTS, pedagogues, doctors, etc. were treated as workers and peasants. At the same time, intelligentsia in the Soviet parliament was traditionally represented by just few persons, despite the fact that this social layer made the most qualitative element of the deputy corpse.

Educational level of the basic quantity of deputies was not high, however, to the SS of the USSR and Ukr. SSR many people with the higher and incomplete higher education were elected. Especially, in the SS of the Ukr. SSR of their second convocation such made up 158 $(38,6 \%)$ and $27(6,5 \%)$ respectively. All the same, people with secondary and elementary education prevailed $(27(6,5 \%)$ with secondary special, $57(13,7)$ with the secondary general, $146(34,7 \%)$ with primary (CSAHAB of Ukraine.Fund1. Description 20. Case 119. Page 4). At local levels an equal quantity of representatives with higher education was, in general, scanty, though an accurate tendency to increase of the general educational level of promoted workers was observed.

At the The quantity of women in representative structures was defined by a quota and made approximately third of all promoted workers. To local Soviets of females selected больший, in particular on equal regional, city and поселковых Soviets. In particular to SS of the Ukr. SSR of the second convocation 112 women (26,99\%) (CSAHAB of Ukraine have been selected approximately.Fund1. Description 18. Case 50. Page 10), and to local Soviets in chest 1947 - 99.770 (32,46 \%) women (CSAHAB of Ukraine.Fund1. Description 18. Case 50. Page 103в.-11). During the third and fourth cadences the proof tendency to increase in quantity of women in representative structures of the power is observed. In particular, to the local Soviets of the third cadence on December, 17, 1950106.828 (33,1\%) women were elected (CSAHAB of Ukraine.Fund1. Description 20. Case 214. Pages 1-7): 6.282 (38,1 \%) were elected to city Soviets of regional and republican subordination, $3.830(38,12 \%)$ to district Soviets of cities, 5.177 (35,11\%) were elected to town Soviets (CSAHAB of Ukraine. Fund1. Description 20. Case 214. Pages 1-7).

From the West Ukrainian regions to the SS of the Ukr. SSR only $23 \%$ of women (out of 115 deputies 27 were women) on February, 9, 1947 were put forward, but it was considerably more, than the number elected to the SS of the Ukr. SSR of the first convocation, wherein women made up only one fifth, and even one sixth (15-20\%) of the general structure of deputies (CSAHAB of Ukraine.Fund1. Description 20. Case 4. Page 11). Such a state of things was explained by a traditional role of the woman in the West Ukrainian society, her dependence on the financial position of the man and her lacking corresponding skills and appropriate education. For example, to the SS of the Ukr. SSR on February, 9, 1947 in Kiev region 8 women, in Kharkiv region 7, in Chernihiv region 6, and in Volhynian region 3, in Drohobych region 4, in Transcarpathian region 2 women were put forward (CSAHAB of Ukraine. Fund1. Description 18. Case 50. Page 10).

The age of the majority of deputies of the investigated period ebbraced 30-40 years, but already then the tendency to parliament ageing was observed. During 2 to 10 convocations 
of the Supreme Soviet of the Ukr.SSR the quantity of deputies of 30-39 years old shortened from $29,8 \%$ to $15,5 \%$, or by $14,3 \%$, of $40-49$ years old shortened from $46,9 \%$ to $30,9 \%$, or by $16 \%$. At the same time,fro, the 2 nd to the 10 th convocations the number of deputies aged 50 grew from $13,5 \%$ to $38,3 \%$, or by $24,8 \%$ (Kravchenko, Tytarenko, 1998: 17-19).

Some part of deputies were elected simultaneously to several representations, because the Soviet elective legislation did not contain any cautions about it. Thus, to the SS of the USSR and Ukr. SSR of the second convocation D. Z. Manuiilskyi, P.N. Reshetniak, M.S. Hrechuha, I.I. Turianytsia, and others were simultaneously elected. Many deputies were «old residents» put forward for 3 to 5 cadences successively which resisted the process of renewal of the representative branch of power. However, such phenomenon as family relationship, so expressively present in the parliament of contemporary Ukraine, was not observed.

Conclusions. So, a restoration of the structure of the deputy corps of different levels in the Ukr. SSR during the post-war period took place with infringement of terms and legislative norms, which was connected with difficult political circumstances, and wishesof officials to keep the influence on the functioning of the representative branch of power. Qualitative characteristics of deputy representation from the West Ukrainian regions of the investigated period considerably differed from the structure of people's electees of the rest of the Ukr. SSR's regions by political, social, national, and gender features, which could be explained by the different historical-political development of the specified territories. Power representatives tried to unify the qualitative structure of representation from the West Ukrainian regions, to make it identical in relation to the other regions of the Ukrainian Soviet Socialist Republic, what, however,was achieved only in the 1960s years. The structure of the representative branch of power in the West Ukrainian regions and the Ukr. SSR on the wholel did not display political and social stratification of the society, and was a result of the artificial quotas established by the power on purpose to show the democratic character of the regime.

\section{BIBLIOGRAPHY}

Власкін, 1966 - Власкін П.О. До питання про роботу партійних організацій Україниз кадрами місцевих Рад (1959-1964) // Український історичний журнал. К., 1966. С. 56-64.

Восленский, 1991 - Восленский М. Номенклатура. М.:Советская Россия, МП Октябрь, $1991.624 \mathrm{c}$.

Докаш, 2013 - Докаш О.Ю. Політика відновлення органів влади та управління західних областей УРСР на завершальному етапі Другої світової війни: структурно-кадровий зріз // Наука і сучасність: виклики глобалізації. (Міжнародна конференція, м. Київ, 25 травня 2013 р.). Част. II (юридичні науки, педагогічні науки, політичні науки). К.: Центр наукових публікацій, 2013. С. 131-135.

Історія державної служби, 2009 - Історія державної служби в Україні. У 5-ти томах. Головне управління державної служби України Інститут історії України Національної академії наук України / Відп. Ред. Т. В. Мотренко, В. А. Смолій. К.: Ніка-Центр, 2009. Т. 2. 536 с.

Кірсанова, 1981 - Кірсанова О. Я. Розвиток суспільно-політичної активності трудящих західних областей УРСР у процесі будівництва основ соціалізму. К.: Наукова думка, 1981. 224 с.

Кондратюк, 2005 - Кондратюк К., Леськів М. Формування репресивного апарату тоталітарного режиму в західних областях України $(1944$ - 1953) // Наукові зошити історичного факультету Львівського національного університету ім. І. Франка: зб. наук, праць. Львів, ЛНУ імені Івана Франка, 2005. Вип. 7. С. 339-346.

Кравченко, 1998; Титаренко, 1998 - Кравченко В. Титаренко Ю. Державотворення в Україні. Історія та сучасність. Донецьк, 1998. С. 17-19.

Трофим'як, 1970 - Трофим'як Ю.М. Добір і виховання керівних кадрів 3 активу жінок: (На матеріалах західних областей УРСР, 1946-1955рр.) // Наукові праці з історії КПРС. К., 1970. Вип. 37. С. 123-130. 
Список депутатів - Список депутатів BP CPCP першого скликання // URL: chttps://uk.wikipedia.org/wiki

ГДА СБУ - Галузевий державний архів Служби Безпеки України, м.Київ

ДАЛО - Державний архів Львівської області.

ЦДАВО України - Центральний державний архів вищих органів влади України.

\section{REFERENCES}

Vlaskin, 1966 - Vlaskin P.O. Do pytannia pro robotu partiinykh orhanizatsii Ukrainy z kadramy mistsevykh Rad (1959-1964) [On the work of the party organizations of Ukraine with the cadres of the local Sovietsin 1959-1964] // Ukrainskyi istorychnyi zhurnal. K., 1966. Pp. 56-64. [in Ukrainian]

Voslenskyi, 1991 - Voslenskyi M. Nomenklatura [Nomenclature]. M.: Sovetskaia Rossyia, MP Oktiabr, 1991. 624 p. [in Russian]

Dokash, 2013 - Dokash O. Yu. Polityka vidnovlennia orhaniv vlady ta upravlinnia zakhidnykh oblastei URSR na zavershalnomu etapi Druhoi svitovoi viiny: strukturno-kadrovyi zriz [The policy of renovation of organs of power and administration of the western regions of Ukraine at the final stage of WWII: a structurals ection of cadres] // Nauka i suchasnist: vyklyky hlobalizatsii. (Mizhnarodna konferentsiia, m. Kyiv, 25 travnia 2013 r.). Chast. II (iurydychni nauky, pedahohichni nauky, politychni nauky). - K.: Tsentr naukovykh publikatsii, 2013. P. 131-135. [in Ukrainian]

Istoriia derzhavnoi sluzhby, 2009 - Istoriia derzhavnoi sluzhby v Ukraini. U 5-ty tomakh. [The history of the state service in Ukraine. In 5 volumes] Holovne upravlinnia derzhavnoi sluzhby Ukrainy Instytut istorii Ukrainy Natsionalnoi akademii nauk Ukrainy. / Vidp. Red. T. V. Motrenko, V. A. Smolii. K.: Nika-Tsentr, 2009. T. 2. 536 p. [in Ukrainian]

Kirsanova, 1981 - Kirsanova O. Ya. Rozvytok suspilno-politychnoi aktyvnosti trudiashchykh zakhidnykh oblastei URSR u protsesi budivnytstva osnov sotsializmu [The development of social-political activity of workers of the western regions of Ukraine in the process of building of the bases of socialism in Ukraine] / O. Ya. Kirsanova. K.: Naukova dumka, 1981. - 224 p. [in Ukrainian]

Kondratiuk, Leskiv,2005 - Kondratiuk K., Leskiv M. Formuvannia represyvnoho aparatu totalitarnoho rezhymu $\mathrm{v}$ zakhidnykh oblastiakh Ukrainy (1944 - 1953) [The formation of the totalitarian apparatus in the western regions of Ukraine (1944 - 1953)] // Naukovi zoshyty istorychnoho fakultetu Lvivskoho natsionalnoho universytetu im. I. Franka: zb. nauk, prats. Lviv, LNU imeni Ivana Franka, 2005. Vyp. 7. P. 339-346. [in Ukrainian]

Kravchenko, Tytarenko, 1998 - Kravchenko V. Tytarenko Yu. Derzhavotvorennia v Ukraini. Istoriia ta suchasnist [The state creation in Ukraine. Its history and contemporaneity]. Donetsk, 1998. Pp. 17-19.[inUkrainian]

Trofym'iak, 1970 - Trofymiak Yu.M. Dobir i vykhovannia kerivnykh kadriv z aktyvu zhinok: (Na materialakh zakhidnykh oblastei URSR, 1946-1955 rr. [Selection and upbringing of managing cadres from women-activists (On the materials of the western regions of Ukraine 1946-1955)]) // Naukovi pratsi z istorii KPRS. K., 1970. Vyp. 37. Pp. 123-130. [in Ukrainian]

Spysok deputativ - Spysok deputativ VR SRSR pershoho sklykannia [The list of deputies of the SS of the USSR of the first convocation] // URL: shttps://uk.wikipedia.org/wiki [in Ukrainian]

HDA SBU - Haluzevyi derzhavnyi arkhiv Sluzhby Bezpeky Ukrainy [The branch state archive of the Security Service of Ukraine], m. Kyiv.

DALO - Derzhavnyi arkhiv Lvivskoi oblasti [The state archive of Lviv oblast].

TsDAVO Ukrainy - Tsentralnyi derzhavnyi arkhiv vyshchykh orhaniv vlady Ukrainy [The central stae archive of the higher bodies of power of Ukraine].

Стаття надійшла до редакиії 10.04.2018 p. 